\title{
The role of community of inquiry and self-efficacy on accounting students' satisfaction in online learning environment
}

\author{
Fachmi Pachlevi Yandra ${ }^{1 *}$, Badr Alsolami², Ivana Oktarina Sopacua ${ }^{3}$, Wisnu Prajogo ${ }^{4}$ \\ ${ }^{1,3}$ Department of Accounting, YKPN Business School, Yogyakarta, Indonesia \\ ${ }^{2}$ Faculty of Islamic Architecture, College of Engineering and Islamic Architecture, Umm Al-Qura \\ University, Mecca, Saudi Arabia \\ ${ }^{4}$ Department of Management, YKPN Business School, Yogyakarta, Indonesia \\ *Corresponding author: fachmi@stieykpn.ac.id
}

\begin{abstract}
The Community of Inquiry (CoI) framework provides a solid guideline for researchers to investigate a quality of online learning. However, there are still very limited studies that explore the pattern of relationships between Col framework and accounting students' satisfaction in online learning. In the context of online learning, self-efficacy plays a role to determine the level of students' confidence to get success in the learning process. Students with a high level of self-efficacy will not perceive a difficult task as an obstacle to be avoided, but rather as a challenge to develop abilities. This research aims to explore the relationship between Col framework and accounting students' satisfaction through online learning self-efficacy. Self-administered survey was conducted to 437 accounting students. Hypothesis was tested using SEM-PLS. Results showed that Col framework were good predictors of accounting students' satisfaction. Different from most studies, this research found that students were more influenced by social presence instead of teaching presence. Higher educational institutions needed to focus on how to improve social presence in the online learning environment. In addition, higher educational institutions needed to manage students' online learning selfefficacy instead of technology self-efficacy.
\end{abstract}

Keywords: Col framework, online learning self-efficacy, accounting students' satisfaction JEL Classification Code: M12, M15, M00 DOI: 10.20885/jsb.vol25.iss1.art1

\section{Introduction}

The phenomenon of covid-19 has forced many higher education institutions in the world, including Indonesia, to conduct online learning. The problem is almost all educational institutions in Indonesia only conduct conventional learning so far. Only a few educational institutions have experience in conducting structured online learning. On the other hand, students also have limited access to technology and the internet. Effectiveness of online learning is difficult to be achieved.

This issue is important to be a concern because of two things. First, the uncertainty of when a pandemic will end, so that online learning at higher education is more likely will take quite a long time. Second, online learning that occurs in most higher education institutions today is an alternative way that must be chosen to save the learning process. This process is certainly different from online learning conducted based on students' needs. Online learning that occurs before a pandemic is only done by a few higher education institutions. This learning is a necessity for workers who have limited time to attend conventional learning. However, online learning that occurs in majority of educational institutions in Indonesia currently is the only one way out could be selected. The consequences are many obstacles arise because most online learning processes that are taking place currently tend to be forced by circumstances. It needed a strategy to improve the process, in order to have better effectiveness.

Alqurashi (2018) stated that students' satisfaction reflects students' learning experience. Empirically, it is also proven that students' satisfaction has strong correlation to the level of drop-out 
students, motivation, commitment, and level of success in online learning (e.g. Yukselturk \& Yildirim, 2008; Ali \& Ahmad, 2011). Previous research confirmed that students' satisfaction is an indicator that has an important role in determining the level of effectiveness of online learning (Fortin et al., 2019; Guest et al., 2018; Landrum et al., 2020). The higher the level of students' satisfaction, the higher the level of effectiveness of online learning will be.

This research focused on accounting students' satisfaction because Kamalluarifin et al. (2018) confirmed that blended learning has a significant relationship on satisfaction of students who are taking advanced accounting information system and auditing courses. It signals that accounting courses are a unique in that they can be taught offline and online. Choo et al. (2020) also conducted a survey of undergraduate accounting and finance students and found that teaching presence has a significant impact on online course rate.

On the other hand, previous studies on online learning (e.g. Garrison \& Arbaugh, 2007; Garrison et al., 2010; Swan \& Ice, 2010) confirmed that The Community of Inquiry (CoI) is a good theoretical framework for understanding the online learning process. Moreover, Castellanos-Reyes (2020) said that The Col framework provides a solid guideline for researchers to investigate online course transcripts. The Col framework suggests that there are three main components in managing and maintaining the effectiveness of online learning in an educational environment, that is: teaching presence, social presence, and cognitive presence (Akyol \& Garrison, 2008). The three main components of the Col framework are the dynamics of the online learning experience which are very important to improve and manage the quality of online learning (Garrison et al., 2010)

Various studies have been carried out to test the Col presences in the context of online learning (e.g. Choo et al., 2020; English et al., 2019; Garrison et al., 2010; Kozan \& Richardson, 2014; Lee et al., 2020; Nagel \& Kotzé, 2010; Richardson et al., 2017). Results of that studies consistently showed that Col presences is an effective framework affecting students' satisfaction in online learning. However, there are still very limited studies that explore how the pattern of relationships formed between Col presences and accounting students' satisfaction in online learning. Empirical testing is needed to explore and test conceptual model relationships among these variables. Evaluation of the determinants of students' satisfaction allows higher education institutions to detect areas that need to be improved in online learning (Kuo et al., 2014).

In psychology disciplines, there is a personal variable that is considered as a key component in the context of learning and students' satisfaction, namely self-efficacy (Alqurashi, 2018). Selfefficacy is defined as the level of confidence person to complete a task, activity, action or challenge (Alqurashi, 2016). In the context of online learning, self-efficacy plays a role to determine the level of students' confidence to get success in the learning process. If students believe that they will not succeed, they will not make any effort to make themselves successful. Meanwhile, students with a high level of self-efficacy will not perceive a difficult task as an obstacle to be avoided, but rather as a challenge to develop abilities (Alqurashi, 2018). In the end, it triggers an increase in performance and leads to higher satisfaction.

Previous research about self-efficacy in an online learning environment has been quite a lot and found mixed results. Lim (2001) found that computer self-efficacy was able to predict students' satisfaction. Womble (2007) also found that computer self-efficacy had a significant positive relationship with students satisfaction. Simmering et al. (2009) found that computer self-efficacy was not related to learning motivation. Wu et al. (2010) also found that computer self-efficacy had no significant effect on students' satisfaction. Tang \& Tseng (2013) found that internet self-efficacy was able to predict students' performance. Meanwhile, Kuo et al. (2014) found that internet selfefficacy was not related to students' satisfaction. The various previous findings indicate at least two things. First, there are still inconsistencies results of study on self-efficacy and students' satisfaction. Second, research on self-efficacy in the context of online learning more focuses on technological aspects, such as computer self-efficacy and internet self-efficacy. There are still very limited studies that focus on learning self-efficacy itself. So far, only four studies have been found that focus on 
this, that is Artino (2008), Gunawerdana et al. (2010), Shen et al. (2013) and Alqurashi (2018). All four of these studies investigated the relationship between online learning self-efficacy and students' satisfaction. They found that self-efficacy is the most powerful predictor of the students' satisfaction in online learning.

Alqurashi (2016) explained that there has been a shift in technology self-efficacy in the context of online learning. Students (millennial generation) have wider and easier access to technology, so that the level of confidence for using technology in online learning is now less likely to predict students' satisfaction. Although technology is the main medium in the online learning process, students have used technology more than just for the learning process, but also for social life. Alqurashi (2018) suggested that the research focus should also shift from self-efficacy for the use of technology and becomes self-efficacy in the online learning process itself, which is the level of confidence about their ability to perform, learn, engage, and finish online learning with success.

Based on that theoretical background, this research aims to explore the relationship of teaching presence, social presence, and cognitive presence on accounting students' satisfaction through online learning self-efficacy. Investigation of the relationship between the Col presences and students' satisfaction through online learning self-efficacy will clearly show which Col components are the strongest for improving self-efficacy and students' satisfaction. Other than that, it also explains whether there is interaction among Col presence to influence self-efficacy and students' satisfaction. The result of this research will help practitioners of various higher educational institutions to determine the right strategy in maintaining the effectiveness of online learning process.

\section{Literature Review and Hypothesis}

\section{Teaching Presence, Online Learning Self-Efficacy, and Students' Satisfaction}

The Col framework is one of the best-known conceptual frameworks for understanding online learning process (Akyol \& Garrison, 2008; Alqurashi, 2018; Kozan \& Caskurlu, 2018; Swan et al., 2009; Swan \& Ice, 2010). This theory explains that there are three main elements that can be used together to create and manage an effective online learning process in an educational environment, that is: teaching presence, social presence, and cognitive presence (Akyol \& Garrison, 2008; English et al., 2019; Kozan \& Richardson, 2014; Swan et al., 2009; Tan et al., 2020).

Anderson et al., (2001) explained that teaching presence is the design, facilities, and direction of social cognitive processes for the purpose of realizing meaningful and educational learning outcomes. The key components of teaching presence are organization and design, discussion facilities, and direct instruction (Anderson et al., 2001). Teaching presence creates opportunities for meaningful learning and ensures that the desired learning outcomes are achieved when supervision and management are carried out with the aim of collaboration and reflection (Garrison et al., 2010).

Anderson et al. (2001) explained that the aspects of design and organization in teaching presence are aspects of planning, process, interaction, and evaluation in online learning. Some examples of real activities from this aspect include making Power Point presentations, making material in the form of video/audio, providing personal insights into lecture materials, and providing guidance on how to use learning media effectively (Arbaugh, 2008). In other words, the design and organizational aspects of teaching presence are a way for lecturers to manage and evaluate online learning activities. This activity is a part that must be completed before the learning starts, although adjustments are very possible when the learning process is running.

The discussion facility aspect is an aspect that makes it easier for students to carry out verbal interactions regarding the information provided in learning. These aspects include information sharing, identification of area agreements and disagreements, and efforts to reach consensus and understanding (Arbaugh, 2008). Therefore, the facility of discussion requires 
lecturers to conduct review and comment on the opinions and questions from students, observing the discussion to be in a desired path, keeping the discussion in order to run efficiently, attracting students who are less active, and limited the activities of individuals who dominate when it undermines classroom discussion (Anderson et al., 2001; Brower, 2003; Coppola et al., 2002; Shea et al., 2003).

Direct instruction as the last aspect of teaching presence is understood as a lecturer determination on intellectual leadership through sharing information and knowledge with students (Anderson et al., 2001). Direct instruction also focuses on assessing the discussion and efficacy of the educational process, so that the lecturer is responsible for providing assessment and feedback (Arbaugh, 2008). In practical, Anderson et al. (2001) provided an example of direct instruction in learning, which are: 1) give the question/ask students; 2) conclude/summarize the results of the discussion; 3) confirm understanding; 4) diagnose misconceptions.

Based on social cognitive theory, Bandura (1991) defined self-efficacy as individual beliefs about their ability to manage and execute actions to achieve expected performance. In online learning environment, self-efficacy is not only the result of students analysis and reflection on the complexity of the task at hand, but also the results of expectations about the degree of their ability to demand specific assignments (Shea \& Bidjerano, 2010). If students believe that they will not succeed, they will not make any effort to make themselves successful. Meanwhile, students with a high level of self-efficacy will not perceive a difficult task as an obstacle to be avoided, but rather as a challenge to develop abilities (Alqurashi, 2018).

Based on a systematic review of the literature conducted by Peechapol et al. (2018), there were only two studies that examined the relationship between teaching presence and self-efficacy, that is Lin et al. (2015) who found that teaching presence is able to predict or have a positive relationship with self-efficacy. In more previous studies, Shea \& Bidjerano (2010) also found that teaching presence has a positive relationship with self-efficacy. Very few studies have been found that have examined the relationship between teaching presence and self-efficacy. However, two previous studies confirmed that the existence of teaching presence in online learning was able to increase online learning self-efficacy.

In online learning environment, lecturers must guide students to self-regulated learning through learning activities or designs. Self-efficacy is a crucial element in self-regulated learning because self-efficacy affects the extent to which students are involved and persist in challenging tasks (Crippen \& Earl, 2007). In addition, Cho (2004) also reported that in online learning environment, lecturers can reduce students' feelings of isolation by providing directions for students' progress and learning methods. That is, lecturers can create teaching presence in the form of expression and expectation to inspire students to participate, that will improve online learning self-efficacy (Lin et al., 2015). Based on the description of literature, this research predicts that: H1a: Teaching presence positively influences online learning self-efficacy.

Previous research found that students' satisfaction is good predictors of online learning (Eom \& Ashill, 2016; Kauffman, 2015). Students' satisfaction talks about how students perceive their learning experience and as a fundamental relationship to outcome what is obtained (Sahin \& Shelley, 2008). Yukseltruk \& Yildirim (2008) and Ali \& Ahmad (2011) also showed that students' satisfaction is strongly correlated to the level of drop-out students, motivation, commitment, and level of success in online learning.

Artino (2008), Gunawerdana et al. (2010), Shen et al. (2013) and Alqurashi (2018) had proven that self-efficacy is the most powerful predictor of students' satisfaction in online learning. These studies generally explained that students who complete online learning process with high confidence in their ability to get good results, dare to face the challenges and to plan and evaluate the learning process would have higher students' satisfaction than those not. Based on the description of the literature, this research predicts that: 
H1b: Online learning self-efficacy positively influences students' satisfaction.

Teaching presence emphasizes the design and organizational process, discussion facilities, and hands-on instruction in online learning. If there is no series of learning activities, no timeline, no protocol, no task completion format, and no evaluation criteria, there will certainly be chaos in the online learning environment (Berger, 1999; Hiltz \& Wellman, 1997). This research specifically investigated satisfaction of accounting students. Choo et al. (2020) conducted a survey of undergraduate accounting and finance students and found that teaching presence has a significant impact on online course rate.

The components in teaching presence play an important role in the effectiveness of online learning. Students' satisfaction is a major predictor of the effectiveness of online learning. If there is a positive relationship between teaching presence - self-efficacy of online learning and online learning self-efficacy - students satisfaction, it is expected that there is indirect positive relationship between teaching presence and students' satisfaction. Based on the description of the literature, this research predicts that:

H1c: Teaching presence positively influences students' satisfaction through online learning self-efficacy.

\section{Social Presence, Online Learning Self-Efficacy, and Students' Satisfaction}

Social presence in online learning is understood as the ability of students to project themselves socially and emotionally in mediated communication (Gunawardena \& Zittle, 1997). Like teaching presence, social presence in an online learning environment has three main components, that is open communication, group cohesion, and affective expression (Garrison \& Arbaugh, 2007). Open communication involves ongoing conversation, copying information from others, and expressing opinions. Affective expression includes emotional expression, humor, and self-expression (Lin et al., 2015). All these components will encourage students to participate in online social interactions by creating direct personal relationships (Garrison \& Arbaugh, 2007). The role of social presence in conventional and online learning environments has also been extensively tested in many previous studies (e.g. Arbaugh, 2008; Gunawardena \& Zittle, 1997; Kucuk \& Richardson, 2019; Lin et al., 2015).

Similar to teaching presence, social presence also has a positive relationship with online learning self-efficacy (Shea \& Bidjerano, 2010). They explained that social presence acts as social persuasion which can increase self-efficacy in an online learning environment. Lin et al. (2015) also explained that affective expression and open communication in a social presence are the most essential aspects for managing communities in online learning. Community-based communication situation that is managed properly will make students feel the learning process enjoyable. In the end, open communication situations and affective expressions will increase individual self-efficacy. Based on this description, this research predicts that:

$\mathrm{H} 2 \mathrm{a}$ : Social presence positively influences online learning self-efficacy.

Social presence in online learning has a role as facilitator in cognitive development and critical thinking (Arbaugh, 2008). Several previous studies in the context of online education effectiveness have found a positive relationship between social presence and learning outcomes (e.g. Arbaugh, 2008; Hwang \& Arbaugh, 2006; Kucuk \& Richardson, 2019; Williams et al., 2006). Specifically, these studies stated that social presence encourages students to actively participate in class discussions. When students feel that their existence is recognized by their social environment (in the context of online learning), it is very likely that they are motivated to get better results and they will feel satisfied with the learning process. If social presence has a positive relationship with online learning self-efficacy and self-efficacy can increase students' satisfaction, this research guessed that there is an indirect positive relationship between social presence and students' satisfaction. Thus, the proposes hypothesis is as follow:

$\mathrm{H} 2 \mathrm{~b}$ : Social presence positively influences students' satisfaction through online learning self-efficacy. 


\section{Cognitive Presence, Online Learning Self-Efficacy, and Students' Satisfaction}

Garrison et al. (2001) described cognitive presence as a students' ability to build and confirm meaning based on continuous and critical thinking and communication. In the Col framework, social presence is considered a source of success or success from learning experiences (Vaughan \& Garrison, 2005). Cognitive presence in online learning is developed as the result of the following four phases. 1) A triggering event, in which several problems were identified for further investigation; 2) Exploration, where students explore problems both individually and collectively through critical reflection; 3) Integration, where students build a meaning of ideas developed during exploration; 4) Resolution, in which students apply newly acquired knowledge to educational and work contexts (Garrison et al., 2001).

Online learning self-efficacy is understood as the level of individual confidence in facing the online learning process. The higher the student's self-efficacy level, the higher the motivation to complete online learning with satisfactory results. High motivation that grows in students will stimulate them to think critically while undergoing the learning process. The critical thinking process is a dimension that is owned in cognitive presence, so it is very predictable that onlinelearning self-efficacy will bring cognitive presence in online learning. Linnenbrink \& Pintrich (2003) stated that students with high self-efficacy are able to engage in activities or strategies with a higher cognitive level. Based on this description, this research predicts that:

H3a: Online learning self-efficacy positively influences cognitive presence.

Since cognitive presence is understood as the ability of students to create critical thinking processes in the learning process, this ability will help students to undergo the learning process with satisfying results. When teaching presence and social presence in the Col framework are predicted to increase students' satisfaction, cognitive presence is also expected the same. Kozan \& Richardson (2014) stated that cognitive presence is the center of the learning process. This means that cognitive presence also plays a role in students' success and satisfaction in online learning. Based on this description, this research predicts that:

H3b: Cognitive presence positively influences students' satisfaction through online learning selfefficacy.

\section{Research Method}

Data collection was conducted using a questionnaire. Respondents who were selected as samples were accounting students at STIE YKPN who had gone through an online learning process for one full semester. Samples were randomly selected from various classes/courses and various semester levels. All respondents completed the survey voluntarily at the last online learning meeting.

All instruments used in this research were adoptions and adaptations from various previous studies. The teaching presence variable was measured using an instrument adapted from Arbaugh (2008). The instrument contains eight statement items, with five Likert scales, such as: 1) "The lecturer clearly communicates important online lecture topics"; 2) "Lecturers help students stay involved and participate in productive dialogue"; 3) "The lecturer gave me clear feedback which helped me learn".

Social presence was measured using instruments from Arbaugh (2008). It contains eight statement items, each with five Likert scales, such as: 1) "I feel comfortable speaking through online media"; 2) "I feel comfortable interacting with other students"; 3) "I feel comfortable participating in class discussions"; 4) "I feel that my point of view is recognized by other students".

Cognitive presence was measured using instruments from Arbaugh (2008). It contains five items, each of five Likert scale, such as: 1) " Lecturers provides useful information from various sources that help me learn"; 2) "I am able to apply the knowledge gained in this lecture to the next 
class assignment"; 3) "I am able to apply the knowledge gained in this lecture to work or other nonclass activities".

Online learning self-efficacy was measured using an instrument developed by Shen et al. (2013). It contains eight statement items, each with five Likert scales, like: 1) "I feel I can finish college with good grades"; 2) "I feel I am able to understand complex concepts"; 3) "I am willing to face challenges"; 4) "I feel that I can complete the assignment according to the criteria given by the lecturer".

Students' satisfaction was measured using an instrument adapted from Alqurashi (2018). It contains two statement items, each with five Likert scales, like: 1) "Overall, I am satisfied with my online learning experience "; 2) "This online course meets my needs as a student'".

Table 1 shows demographic characteristics of respondents. The sample chosen in this research were students who had completed a full semester of online learning. The number of responses that can be processed in data analysis were 437 samples. The frequency and percentage of demographic variables shown below were obtained from a questionnaire distributed to each respondent.

Table 1. Respondents' Demographic Profile

\begin{tabular}{llcc}
\hline & Characteristic & Frequency & Percentage \\
\hline Gender & Male & 188 & $43.02 \%$ \\
Total & Female & 249 & $56.98 \%$ \\
Age & & 437 & $100 \%$ \\
& $18-19$ years & 77 & $17.62 \%$ \\
& $20-21$ years & 209 & $47.83 \%$ \\
Total & $22-23$ years & 124 & $28.38 \%$ \\
Semester & $>23$ years & 27 & $6.18 \%$ \\
& & 437 & $100 \%$ \\
& $2-4$ & 189 & $43.25 \%$ \\
Total & $6-8$ & 182 & $41.65 \%$ \\
Technology used & $10-12$ & 60 & $13.73 \%$ \\
& $>12$ & 6 & $1.37 \%$ \\
Total & Computer & 437 & $100 \%$ \\
& Smartphone & 45 & $10.30 \%$ \\
& Both computer \& smartphone & 49 & $11.21 \%$ \\
& & 343 & $78.39 \%$ \\
\hline
\end{tabular}

From Table 1 it can be seen that the majority of respondents were women with a total of $247(56.98 \%)$, and the remaining $188(43.02 \%)$ were male. Of the total 437 respondents, the majority of respondents were in the age range of 20-21 years (47.83\%), followed by 22-23 years (28.38\%), 18-19 years (17.62\%) and above 23 years (6.18\%). Students at second, fourth, sixth, and eighth semester dominated the research sample (84.90\%), the remaining $15.10 \%$ were students in the tenth semester and above. The majority of respondents, $343(78,39 \%)$ students used a computer and smart phone in the process of online learning, only $10.30 \%$ who used computers only, and $11.21 \%$ who used smartphones only.

Table 2 shows the mean scores, min, max, standard deviations, and number of items for each variable and their ranges. The highest mean score among the five variables were teaching presence $(M=3.87 ; S D=0.71)$, followed by OLSE $(M=3.68 ; S D=0.69)$, followed by cognitive presence $(M=3.62 ; S D=0.68)$, and students' satisfaction $(M=3.45 ; S D=0.96)$. Social presence had the smallest mean score $(M=3.43 ; S D=0.73)$. 
The role of community of inquiry and self-efficacy

on accounting students' satisfaction in online learning environment

Table 2. Descriptive Statistics

\begin{tabular}{|c|c|c|c|c|c|c|c|}
\hline \multirow{2}{*}{ Variable } & \multirow{2}{*}{ Items } & \multicolumn{2}{|c|}{ Theoretical Score } & \multicolumn{2}{|c|}{ Actual Score } & \multirow{2}{*}{ Mean } & \multirow{2}{*}{ SD } \\
\hline & & Min & Max & Min & Max & & \\
\hline Teaching Presence & 8 & 1 & 5 & 1.13 & 5.00 & 3.87 & 0.72 \\
\hline Social Presence & 8 & 1 & 5 & 1.00 & 5.00 & 3.43 & 0.73 \\
\hline Cognitive Presence & 5 & 1 & 5 & 1.20 & 5.00 & 3.62 & 0.68 \\
\hline OLSE & 8 & 1 & 5 & 1.50 & 5.00 & 3.68 & 0.69 \\
\hline Students Satisfaction & 2 & 1 & 5 & 1.00 & 5.00 & 3.45 & 0.96 \\
\hline
\end{tabular}

\section{Result}

\section{Validity \& Reliability}

The validity test was conducted to assess the accuracy of the instruments that was used to measure variables. The validity in this research was assessed based on convergent validity and discriminant validity. There were two criteria to conclude that the measurement instrument had acceptable convergent validity, that were, the score for each loading was equal to or greater than 0.5 and the pvalue for each loading was smaller than 0.5 (Hair et al., 2009). Table 3 shows the results of the convergent validity test.

Table 3. Convergent Validity

\begin{tabular}{lccccccc}
\hline & TP & SP & CP & OLSE & SS & SE & P-value \\
\hline TP1 & $(0.809)$ & 0.017 & -0.106 & 0.017 & 0.150 & 0.043 & $<0.001$ \\
TP2 & $(0.812)$ & -0.051 & -0.088 & 0.110 & -0.102 & 0.043 & $<0.001$ \\
TP3 & $(0.874)$ & -0.049 & -0.083 & 0.021 & 0.071 & 0.043 & $<0.001$ \\
TP4 & $(0.850)$ & 0.110 & -0.143 & 0.024 & -0.037 & 0.043 & $<0.001$ \\
TP5 & $(0.844)$ & -0.029 & 0.131 & -0.060 & 0.062 & 0.043 & $<0.001$ \\
TP6 & $(0.868)$ & -0.068 & 0.114 & -0.010 & -0.056 & 0.043 & $<0.001$ \\
TP7 & $(0.855)$ & 0.061 & 0.039 & -0.024 & -0.043 & 0.043 & $<0.001$ \\
TP8 & $(0.859)$ & 0.011 & 0.127 & -0.072 & -0.043 & 0.043 & $<0.001$ \\
\hline SP1 & 0.026 & $(0.725)$ & -0.027 & -0.142 & 0.252 & 0.044 & $<0.001$ \\
SP2 & -0.214 & $(0.773)$ & -0.063 & 0.103 & 0.309 & 0.043 & $<0.001$ \\
SP3 & -0.054 & $(0.847)$ & -0.062 & -0.031 & 0.123 & 0.043 & $<0.001$ \\
SP4 & 0.025 & $(0.795)$ & 0.069 & 0.076 & -0.075 & 0.043 & $<0.001$ \\
SP5 & 0.171 & $(0.823)$ & 0.206 & -0.150 & 0.033 & 0.043 & $<0.001$ \\
SP6 & 0.010 & $(0.785)$ & 0.055 & -0.057 & -0.172 & 0.043 & $<0.001$ \\
SP7 & -0.032 & $(0.745)$ & -0.145 & 0.228 & -0.348 & 0.043 & $<0.001$ \\
SP8 & 0.069 & $(0.704)$ & -0.055 & -0.018 & -0.142 & 0.044 & $<0.001$ \\
\hline CP1 & 0.397 & 0.014 & $(0.790)$ & -0.024 & -0.077 & 0.043 & $<0.001$ \\
CP2 & -0.037 & -0.091 & $(0.869)$ & 0.211 & 0.042 & 0.043 & $<0.001$ \\
CP3 & -0.217 & 0.014 & $(0.855$ & -0.039 & 0.062 & 0.043 & $<0.001$ \\
CP4 & -0.056 & 0.110 & $(0.858)$ & -0.126 & -0.032 & 0.043 & $<0.001$ \\
CP5 & -0.057 & -0.045 & $(0.838)$ & -0.028 & 0.000 & 0.043 & $<0.001$ \\
\hline OLSE1 & 0.084 & 0.026 & -0.187 & $(0.814)$ & 0.122 & 0.043 & $<0.001$ \\
OLSE2 & 0.006 & 0.063 & 0.005 & $(0.729)$ & 0.191 & 0.044 & $<0.001$ \\
OLSE3 & 0.087 & 0.065 & 0.080 & $(0.676)$ & -0.251 & 0.044 & $<0.001$ \\
OLSE4 & 0.001 & -0.204 & 0.103 & $(0.809)$ & -0.050 & 0.043 & $<0.001$ \\
OLSE5 & 0.087 & -0.240 & 0.052 & $(0.732)$ & -0.006 & 0.043 & $<0.001$ \\
OLSE6 & -0.005 & 0.069 & -0.091 & $(0.817)$ & -0.046 & 0.043 & $<0.001$ \\
OLSE7 & -0.139 & 0.140 & 0.089 & $(0.802)$ & 0.073 & 0.043 & $<0.001$ \\
OLSE8 & -0.100 & 0.076 & -0.030 & $(0.798)$ & -0.057 & 0.043 & $<0.001$ \\
\hline SS1 & -0.046 & -0.029 & 0.057 & 0.041 & $(0.934)$ & 0.042 & $<0.001$ \\
SS2 & 0.046 & 0.029 & -0.057 & -0.041 & $(0.934)$ & 0.042 & $<0.001$ \\
\hline
\end{tabular}


All loading scores for each item in Table 3 were above 0.5, there was no cross loading among variables. Table 3 also showed that convergent validity to construct reflective was supported with p-value $<0.5$. Based on Table 3, it can be concluded that the measurement instrument fulfilled the convergent validity assumption.

Table 4 shows information regarding the discriminant validity. The criterion for concluding that the measuring instrument has acceptable discriminant validity is the root of average variance extracted (AVE) for each variable, on the diagonal, must be greater than any of the correlations involving the latent variable (Fornell \& Larcker, 1981). Based on Table 4, it can be concluded that the measurement instrument fulfilled the assumption of discriminant validity, because all AVE scores were the largest in their column or row, except for SP. The correlation between SP and CP was greater than the AVE score, but this difference did not require removing one or more indicators in these variables because there was no cross loading on convergent validity.

Table 4. Discriminant Validity

\begin{tabular}{|c|c|c|c|c|c|}
\hline \multicolumn{6}{|c|}{ Latent Variable Correlations } \\
\hline & TP & SP & $\mathrm{CP}$ & OLSE & SS \\
\hline TP & $(0.847)$ & 0.673 & 0.754 & 0.720 & 0.593 \\
\hline SP & 0.673 & $(0.776)$ & 0.795 & 0.638 & 0.687 \\
\hline $\mathrm{CP}$ & 0.754 & 0.795 & $(0.842)$ & 0.684 & 0.661 \\
\hline OLSE & 0.720 & 0.638 & 0.684 & $(0.774)$ & 0.623 \\
\hline SS & 0.593 & 0.687 & 0.661 & 0.623 & $(0.934)$ \\
\hline \multicolumn{6}{|c|}{$P$ Values for Correlations } \\
\hline & TP & SP & $\mathrm{CP}$ & OLSE & SS \\
\hline TP & 1.000 & $<0.001$ & $<0.001$ & $<0.001$ & $<0.001$ \\
\hline SP & $<0.001$ & 1.000 & $<0.001$ & $<0.001$ & $<0.001$ \\
\hline $\mathrm{CP}$ & $<0.001$ & $<0.001$ & 1.000 & $<0.001$ & $<0.001$ \\
\hline OLSE & $<0.001$ & $<0.001$ & $<0.001$ & 1.000 & $<0.001$ \\
\hline SS & $<0.001$ & $<0.001$ & $<0.001$ & $<0.001$ & 1.000 \\
\hline
\end{tabular}

Table 5 shows the reliability of instrument. Reliability test was conducted to assess the quality of the instruments used in measuring the variables. The measurement instrument has good reliability if the question-statement items on each variable are understood in the same way by different respondents. Reliability instrument is determined by the score Cronbach's alpha and composite reliability. Conservatively, both the Cronbach's alpha and composite reliability must be equal to or greater than 0.7 (Nunnally \& Bernstein, 1994). In Table 5, it can be seen that the Cronbach's alpha score and composite reliability for each variable was higher than 0.7. The measurement instrument fulfilled the reliability assumption.

Table 5. Reliability

\begin{tabular}{lccccc}
\hline & TP & SP & CP & OLSE & SS \\
\hline Cronbach's alpha & 0.943 & 0.905 & 0.897 & 0.903 & 0.855 \\
Composite reliability & 0.953 & 0.923 & 0.924 & 0.922 & 0.932 \\
\hline
\end{tabular}

\section{Hypothesis Testing}

The first step that needed to be done is testing the direct effect among teaching presence, social presence, and cognitive presence on students' satisfaction. This test was needed in making decisions on the mediation hypothesis. Table 6 shows the results of the direct effect among these variables. These results indicated that the three independent variables had a significant positive relationship on the dependent variable. 
Furthermore, this research used a structural equation modeling (SEM) approach to investigate the structural relationship among variables. The type of SEM used was structural equation modelling (SEM PLS). The SEM PLS statistical tool was chosen because this research aimed to explore and develop the theory of Col presence in the context of online learning. The hypothesis testing was carried out by estimating the indirect effect simultaneously. SEM test results can be seen in Figure 1.

Table 6. Direct Effects

\begin{tabular}{lcccc}
\hline Path & Path Coefficient & P Values & R-Squared & Result \\
\hline TP - SS & 0.15 & $<0.01$ & 0.53 & Significant \\
SP - SS & 0.42 & $<0.01$ & 0.53 & Significant \\
CP - SS & 0.21 & $<0.01$ & 0.53 & Significant \\
\hline
\end{tabular}

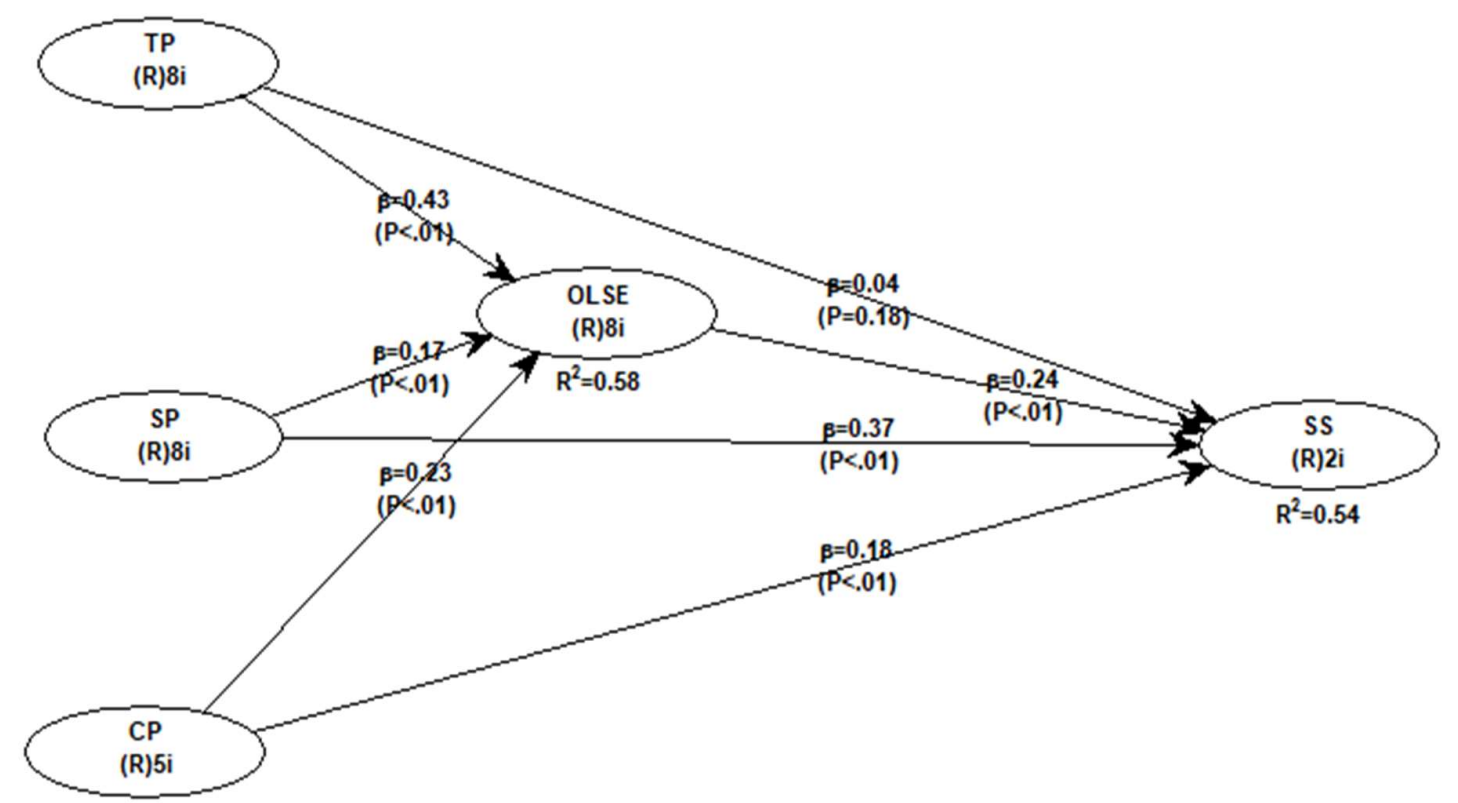

Figure 1. SEM-PLS

Specifically, Table 7 shows the results of hypothesis testing among Teaching Presence (TP), Social Presence (SP), Cognitive Presence (CP), Online Learning Self Efficacy (OLSE), and Students' Satisfaction (SS). The results showed that TP had a significant positive relationship with OLSE $(B=0.43 ; p<0.01)$. H1a was supported. SP had a significant positive relationship with OLSE $(B=0.17 ; p<0.01)$. H2a was supported. CP also had a positive relationship to OLSE $(B=0.23$; $p<0.01)$. H3a was supported. The first condition to support the mediation hypothesis had been fulfilled.

Table 7. Hypothesis Testing

\begin{tabular}{lcccc}
\hline Path & Path Coefficient & P Values & R-Squared & Result \\
\hline TP - OLSE & 0.43 & $<0.01$ & 0.58 & Significant \\
SP - OLSE & 0.17 & $<0.01$ & 0.58 & Significant \\
CP - OLSE & 0.23 & $<0.01$ & 0.58 & Significant \\
OLSE - SS & 0.24 & $<0.01$ & 0.54 & Significant \\
TP - SS & 0.04 & 0.18 & 0.54 & Not significant \\
SP - SS & 0.37 & $<0.01$ & 0.54 & Significant \\
CP - SS & 0.18 & $<0.01$ & 0.54 & Significant \\
\hline
\end{tabular}


The second requirement to support the mediation hypothesis was there was a significant positive relationship between OLSE and SS. The results showed that OLSE and SS had a significant positive relationship $(B=0.24 ; p<0.01)$. $\mathrm{H} 1 \mathrm{~b}$ was supported. The mediation hypothesis was tested by comparing beta coefficient and p-value between structural model and the direct effect test. If there is a decrease in beta coefficient score and p-value becomes insignificant on the structural model, full mediation can be obtained. If there is a decrease in beta coefficient score but p-value is still significant on the structural model, there is partial mediation. If there is no decrease in beta coefficient score on the structural model, there is no mediation.

The relationship between TP and SS in the direct effect showed $B=0.15$ and $\mathrm{p}<0.01$ while in the structural model showed $B=0.04$ and $p=0.18$. There was a decrease in beta coefficient score and p-value became insignificant when OLSE was included in the model. That is, OLSE fully mediated the relation between TP and SS. Hypothesis 1c was supported. SP and SS in the direct effect showed $B=0.42$ and $p<0.01$ while in the structural model $B=0.37$ and $p<0.01$. There was a decrease in beta coefficient score, but p-value remained significant when OLSE was included in the model. That is, OLSE partially mediated the relation between SP and SS. Hypothesis $2 \mathrm{~b}$ was supported. CP and SS in the direct effect showed $B=0.21$ and $p<0.01$ while the structural model showed $B=0.18$ and $p<0.01)$. There was a decrease in beta coefficient score when OLSE was included in the model, but p-value still significant. This means that OLSE partially mediated the relation between CP and SS. Hypothesis $3 \mathrm{~b}$ was supported.

\section{Discussion}

This research aims to investigate the relationship between Col presences and students' satisfaction through online learning self-efficacy. The results showed that teaching presence, social presence, and cognitive presence were good predictors of students' satisfaction. These results were consistent with Giannousi \& Kioumourtzoglou (2016) who found that all three components of the Col presence significantly predicted satisfaction. In contrast to previous findings which found that teaching presence was the most dominant determinant of satisfaction (e.g. Estelami, 2012; Kranzow, 2013; Kucuk \& Richardson, 2019; Ladyshewsky, 2013; M. N. \& Quick, 2016), this research found that social presence was the strongest determinant to students' satisfaction. Social presence had a role as facilitator in cognitive development and critical thinking in online learning (Arbaugh, 2008).

This research also found that teaching presence, social presence, and cognitive presence could predict online learning self-efficacy. This finding was consistent with the research of Shea \& Bidjerano (2010) and Lin et al. (2015). In online learning environment, lecturers must guide students to self-regulated learning through learning activities or designs. Self-efficacy is a crucial element in self-regulated learning because self-efficacy affects the extent to which students re involved and persist in challenging tasks (Crippen \& Earl, 2007). Lecturers can create teaching presence in the form of expression and expectation to inspire students to participate, that will improve online learning self-efficacy (Lin et al., 2015). In addition, social presence also increases online learning self-efficacy because community-based communication situation that is managed properly will make students feel the learning process enjoyable, finally open communication situations and affective expressions will increase individual self-efficacy.

The last finding in this research was the role of online learning self-efficacy as a mediating variable between Col presence and students' satisfaction. This research found that online learning self-efficacy fully mediated the relationship between teaching presence and students' satisfaction, while social presence and cognitive presence were only partially mediated by online learning selfefficacy to students' satisfaction. The findings of this research indicated that Col presences could increase students' satisfaction by increasing online learning self-efficacy. Teaching presence could only increase students' satisfaction if students had self-efficacy of online learning. 


\section{Conclusion}

Understanding the determinants of students' satisfaction can make a significant contribution to online learning practice and theory. Students' satisfaction is a variable that has an important role in determining the effectiveness of online learning. Yukseltruk \& Yildirim (2008) and Ali \& Ahmad (2011) proved that students' satisfaction has strong correlation to the level of drop-out students, motivation, commitment, and the level of success in online learning. By understanding social presence as the most dominant variable to influence students' satisfaction, higher educational institutions need to focus on how to improve social presence in the online learning environment. In addition, higher educational institutions need to manage students' online learning self-efficacy instead of technology self-efficacy.

Since this research specifically investigated accounting students' satisfaction, these finding had specific implication for accounting lecturers. Different from previous research, this research found that accounting students were more influenced by social presence instead of teaching presence. It signals that the most effective way to improve the quality and effectiveness of online learning was to encourage accounting students to actively participate in class discussion. When students feel their existence was recognized by their social environment, it was very likely that they were motivated to get better results, and finally they would be satisfied with the learning process.

Finally, this research filled the limited studies about Col presence, online learning selfefficacy, and student's satisfaction. However, this research still has some limitations. Firstly, this study was self-reported to measure their self-efficacy. There is potential for bias in self-assessment. Further research is possible by conducting an interview process using an enumerator. Secondly, the respondents or samples in this research were students who were 'forced' to do the online learning process. Hence, the results may be different if the sample is students who undertake online learning out of desire. Future research might be comparing the responses between students who carry out online learning because of certain circumstances and students who carry out online learning because of their desire.

\section{References}

Akyol, Z., \& Garrison, D. R. (2008). The development of a community of inquiry over time in an online course: Understanding the progression and integration of social, cognitive, and teaching presence. Journal of Asynchronous Learning Networks, 12(3), 3-22. https://doi.org/10.24059/olj.v12i3.66

Ali, A., \& Ahmad, I. (2011). Key factors for determining student's satisfaction in distance learning courses: A study of Allama Iqbal Open University (AIOU) Islamabad, Pakistan. Turkish Online Journal of Distance Education, 12(2), 114-127. https://doi.org/10.17718/tojde.10766

Alqurashi, E. (2016). Self-efficacy in online learning environments: A literature review. Contemporary Issues in Education Research, 9(1), 45-52.

Alqurashi, E. (2018). Predicting student's satisfaction and perceived learning within online learning environments. Distance Education, 401), 133-148. https://doi.org/10.1080/ 01587919.2018 .1553562

Anderson, T., Rourke, L., Garrison, D. R., \& Archer, W. (2001). Assessing teaching presence in a computer conferencing context. Journal of Asynchronous Learning Network, 5(2). https://doi.org/10.24059/olj.v5i2.1875

Arbaugh, J. B. (2008). Does the Community of Inquiry framework predict outcomes in online MBA courses? International Review of Research in Open and Distance Learning, 9(2), 1-21.

Artino, A. R. (2008). Motivational beliefs and perceptions of instructional quality: Predicting satisfaction with online training. Journal of Computer Assisted Learning, 24(3), 260-270. 
https://doi.org/10.1111/j.1365-2729.2007.00258.x

Bandura, A. (1991). Social cognitive theory of self-regulation. Organizational Behavior and Human Decision Processes, 50(2), 248-287. https://doi.org/10.1016/0749-5978(91)90022-L

Berger, N. S. (1999). Pioneering experiences in distance learning: Lessons learned. Journal of Management Education, 23(6), 684-690. https://doi.org/10.1177/105256299902300606

Brower, H. H. (2003). On Emulating Classroom Discussion in a Distance-Delivered OBHR Course: Creating an On-Line Learning Community. Academy of Management Learning \& Education, 2(1), 22-36. https://doi.org/10.5465/amle.2003.9324013

Castellanos-Reyes, D. (2020). 20 Years of the Community of Inquiry Framework. TechTrends, 64(4), 557-560. https://doi.org/10.1007/s11528-020-00491-7

Cho, M. H. (2004). The Effects of Design Strategies for Promoting Students' Self-Regulated Learning Skills on Students' Self-Regulation and Achievements in Online Learning Environments. Association for Educational Communications and Technology, 27(1999), 19-23. http://www.acousticslab.org/dots_sample/module4/Cho2004_SelfRegulatedLearning.pdf

Choo, J., Bakir, N., Scagnoli, N. I., Ju, B., \& Tong, X. (2020). Using the Community of Inquiry Framework to Understand Students' Learning Experience in Online Undergraduate Business Courses. TechTrends, 64(1), 172-181. https://doi.org/10.1007/s11528-019-00444-9

Coppola, N. W., Hiltz, S. R., \& Rotter, N. G. (2002). Becoming a virtual professor: Pedagogical roles and asynchronous learning networks. Journal of Management Information Systems, 18(4), 169-189. https://doi.org/10.1080/07421222.2002.11045703

Crippen, K. J., \& Earl, B. L. (2007). The impact of web-based worked examples and self-explanation on performance, problem solving, and self-efficacy. Computers and Education, 49(3), 809821. https://doi.org/10.1016/j.compedu.2005.11.018

English, M., West, P., \& Jackson, J. (2019). Building a Community of Inquiry in Online Library Instruction: The Col Framework Applied. Journal of Library and Information Services in Distance Learning, 13(3), 283-293. https://doi.org/10.1080/1533290X.2019.1575319

Eom, S., \& Ashill, N. J. (2016). The Determinants of Students' Perceived Learning Outcomes and Satisfaction in University Online Education: An Update. Decision Sciences Journal of Innovative Education, 14(April), 185-215. https://doi.org/10.1109/CONMEDIA46929.201 9.8981813

Estelami, H. (2012). An Exploratory Study of the Drivers of Students Satisfaction and Learning Experience in Hybrid-Online and Purely Online Marketing Courses. Marketing Education Review, 22(2), 143-156. https://doi.org/10.2753/mer1052-8008220204

Fornell, C., \& Larcker, D. (1981). Evaluating structural equation models with unobservable variables and measurement error. Journal of Marketing Research, 18(1), 39-50. https://doi.org/10.1016/j.jaci.2012.05.050

Fortin, A., Viger, C., Deslandes, M., Callimaci, A., \& Desforges, P. (2019). Accounting students' choice of blended learning format and its impact on performance and satisfaction. Accounting Education, 28(4), 353-383. https://doi.org/10.1080/09639284.2019.1586553

Garrison, D. R., Cleveland-Innes, M., \& Fung, T. S. (2010). Exploring causal relationships among teaching, cognitive and social presence: Students perceptions of the community of inquiry framework. Internet and Higher Education, 13(1-2), 31-36. https://doi.org/10.1016/j.iheduc.2009.10.002

Garrison, D. Randy, Anderson, T., \& Archer, W. (2001). Critical thinking, cognitive presence, and 
computer conferencing in distance education. International Journal of Phytoremediation, 21(1), 7-23. https://doi.org/10.1080/08923640109527071

Garrison, D. Randy, \& Arbaugh, J. B. (2007). Researching the community of inquiry framework: Review, issues, and future directions. Internet and Higher Education, 10(3), 157-172. https://doi.org/10.1016/j.iheduc.2007.04.001

Giannousi, M., \& Kioumourtzoglou, E. (2016). Cognitive, Social, and Teaching Presence as Predictors of Students' Satisfaction in Distance Learning. Mediterranean Journal of Social Sciences, 7(2), 439-447. https://doi.org/10.5901/mjss.2016.v7n2s1p439

Guest, R., Rohde, N., Selvanathan, S., \& Soesmanto, T. (2018). Students satisfaction and online teaching. Assessment and Evaluation in Higher Education, 43(7), 1084-1093. https://doi.org/10.1080/02602938.2018.1433815

Gunawardena, C. N., Linder-VanBerschot, J. A., LaPointe, D. K., \& Rao, L. (2010). Predictors of learner satisfaction and transfer of learning in a corporate online education program. American Journal of Distance Education, 24(4), 207-226. https://doi.org /10.1080/08923647.2010.522919

Gunawardena, C. N., \& Zittle, F. J. (1997). Social presence as a predictor of satisfaction within a computer-mediated conferencing environment. International Journal of Phytoremediation, 21(1), 8-26. https://doi.org/10.1080/08923649709526970

Hair, J.., Black, W.., Babin, B.., \& Anderson, R. (2009). Multivariate data analysis. Upper Saddle River, NJ: Prentice Hall.

Hiltz, S. R., \& Wellman, B. (1997). Asynchronous Learning Networks as a Virtual Classroom. Communications of the ACM, 4O9), 44-49. https://doi.org/10.1145/260750.260764

Hwang, A., \& Arbaugh, J. B. (2006). Virtual and Traditional Feedback-Seeking Behaviors: Underlying Competitive Attitudes and Consequent Grade Performance. Decision Sciences Journal of Innovative Education, 4(1), 1-28. https://doi.org/10.1111/j.15404609.2006.00099.x

Kamalluarifin, W., Aniza, F., Jayabalan, H., Muhammad Saufi, Bakar, N., \& Karib, S. (2018). Blended learning: satisfaction among accounting students in UNITEN KSHAS. Global Business \& Management Research, 10(3), 547-557.

Kauffman, H. (2015). A review of predictive factors of students' success in and satisfaction with online learning. Research in Learning Technology, 23(1063519), 1-14. https://doi.org/10.3402/rlt.v23.26507

Kozan, K., \& Caskurlu, S. (2018). On the Nth presence for the Community of Inquiry framework. Computers and Education, 122(May 2017), 104-118. https://doi.org/10.1016/j.compedu.2018.03.010

Kozan, K., \& Richardson, J. C. (2014). Interrelationships between and among social, teaching, and cognitive presence. Internet and Higher Education, 21, 68-73. https://doi.org/10.1016/j.iheduc.2013.10.007

Kranzow, J. (2013). Faculty Leadership in Online Education: Structuring Courses to Impact Students Satisfaction and Persistence. Journal of Online Learning and Teaching, 9(1), 131-139.

Kucuk, S., \& Richardson, J. C. (2019). A structural equation model of predictors of online learners' engagement and satisfaction. Online Learning Journal, 23(2), 196-216. https://doi.org/10.24059/olj.v23i2.1455

Kuo, Y. C., Walker, A. E., Schroder, K. E. E., \& Belland, B. R. (2014). Interaction, Internet self- 
efficacy, and self-regulated learning as predictors of students' satisfaction in online education courses. Internet and Higher Education, 201), 35-50. https://doi.org/10.1016/j.iheduc.2013.10.001

Ladyshewsky, R. K. (2013). Instructor Presence in Online Courses and Students Satisfaction. International Journal for the Scholarship of Teaching and Learning, 7(1), 1-23. https://doi.org/10.20429/ijsotl.2013.070113

Landrum, B., Bannister, J., Garza, G., \& Rhame, S. (2020). A class of one: Students' satisfaction with online learning. Journal of Education for Business, Q0), 1-7. https://doi.org/10.1080/08832323.2020.1757592

Lee, R., Hoe Looi, K., Faulkner, M., \& Neale, L. (2020). The moderating influence of environment factors in an extended community of inquiry model of e-learning. Asia Pacific Journal of Education, OO(00), 1-15. https://doi.org/10.1080/02188791.2020.1758032

Lim, C. K. (2001). Computer self-efficacy, academic self-concept, and other predictors of satisfaction and future participation of adult distance learners. International Journal of Phytoremediation, 21(1), 41-51. https://doi.org/10.1080/08923640109527083

Lin, S., Hung, T. C., \& Lee, C. T. (2015). Revalidate forms of presence in training effectiveness: Mediating effect of self-efficacy. Journal of Educational Computing Research, 53(1), 32-54. https://doi.org/10.1177/0735633115588772

Linnenbrink, E. A., \& Pintrich, P. R. (2003). Reading \& Writing Quarterly: Overcoming Learning Difficulties The role of self-efficacy beliefs in student's engagement and learning. Reading \& Writing Quarterly, 19(2), 119-137. https://doi.org/10.1080/10573560308223

M. N., M. K., \& Quick, D. (2016). Teaching Presence Influencing Online Students' Course Satisfaction at an Institution of Higher Education. International Education Studies, 9(3), 62. https://doi.org/10.5539/ies.v9n3p62

Nagel, L., \& Kotzé, T. G. (2010). Supersizing e-learning: What a Col survey reveals about teaching presence in a large online class. Internet and Higher Education, 13(1-2), 45-51. https://doi.org/10.1016/j.iheduc.2009.12.001

Nunnally, J.., \& Bernstein, I. (1994). Psychometric theory. New York, NY: McGraw Hill.

Peechapol, C., Na-Songkhla, J., Sujiva, S., \& Luangsodsai, A. (2018). An exploration of factors influencing self-efficacy in online learning: A systematic review. International Journal of Emerging Technologies in Learning, 13(9), 64-86. https://doi.org/10.3991/ijet.v13i09.8351

Richardson, J. C., Maeda, Y., Lv, J., \& Caskurlu, S. (2017). Social presence in relation to students' satisfaction and learning in the online environment: A meta-analysis. Computers in Human Behavior, 71, 402-417. https://doi.org/10.1016/j.chb.2017.02.001

Sahin, I., \& Shelley, M. (2008). Considering students' perceptions: The distance education students satisfaction model. Educational Technology and Society, 11(3), 216-223.

Shea, P., \& Bidjerano, T. (2010). Learning presence: Towards a theory of self-efficacy, selfregulation, and the development of a communities of inquiry in online and blended learning environments. Computers and Education, 55(4), 1721-1731. https://doi.org/10.1016/j.compedu.2010.07.017

Shea, P. J., Fredericksen, E. E., Pickett, A. M., \& Pelz, W. E. (2003). A preliminary investigation of "teaching presence" in the SUNY learning network. Elements of Quality Online Education: Practice and Direction, 4, 279-312. http://hdl.handle.net/1802/2783

Shen, D., Cho, M. H., Tsai, C. L., \& Marra, R. (2013). Unpacking online learning experiences: 
Online learning self-efficacy and learning satisfaction. Internet and Higher Education, 19, 10-17. https://doi.org/10.1016/j.iheduc.2013.04.001

Simmering, M. J., Posey, C., \& Piccoli, G. (2009). Computer Self-Efficacy and Motivation to Learn in a Self-Directed Online Course. Decision Sciences Journal of Innovative Education, 7(1), 99-121. https://doi.org/10.1111/j.1540-4609.2008.00207.x

Swan, K., Garrison, D. R., \& Richardson, J. C. (2009). A constructivist approach to online learning: The community of inquiry framework. Information Technology and Constructivism in Higher Education: Progressive Learning Frameworks, January, 43-57. https://doi.org/10.4018/978-1-60566-654-9.ch004

Swan, K., \& Ice, P. (2010). The community of inquiry framework ten years later: Introduction to the special issue. Internet and Higher Education, 13(1-2), 1-4. https://doi.org/10.1016/j.iheduc.2009.11.003

Tan, H. R., Chng, W. H., Chonardo, C., Ng, M. T. T., \& Fung, F. M. (2020). How Chemists Achieve Active Learning Online during the COVID-19 Pandemic: Using the Community of Inquiry (Col) Framework to Support Remote Teaching. Journal of Chemical Education, 97(9), 2512-2518. https://doi.org/10.1021/acs.jchemed.0c00541

Tang, Y., \& Tseng, H. W. (2013). Distance learners' self-efficacy and information literacy skills. Journal of Academic Librarianship, 39(6), 517-521. https://doi.org/10.1016/j.acalib.2013.08.008

Vaughan, N., \& Garrison, D. R. (2005). Creating cognitive presence in a blended faculty development community. Internet and Higher Education, 8(1), 1-12. https://doi.org/10.1016/j.iheduc.2004.11.001

Williams, E. A., Duray, R., \& Reddy, V. (2006). Teamwork orientation, group cohesiveness, and students learning: A study of the use of teams in online distance education. Journal of Management Education, 30(4), 592-616. https://doi.org/10.1177/1052562905276740

Womble, J. (2007). E-learning: The relationship among learner satisfaction, self-efficacy, and usefulness [Alliant International University]. https://www.learntechlib.org/p/119496/

Wu, J. H., Tennyson, R. D., \& Hsia, T. L. (2010). A study of students' satisfaction in a blended elearning system environment. Computers and Education, 55(1), 155-164. https://doi.org/10.1016/j.compedu.2009.12.012

Yukselturk, E., \& Yildirim, Z. (2008). Investigation of interaction, online support, course structure and flexibility as the contributing factors to students' satisfaction in an online certificate program. Educational Technology and Society, 11(4), 51-65. 